\title{
A CRITICAL ASSESSMENT OF THE TURKISH APPAREL INDUSTRY AND FIRMS
}

\author{
Refik CULPAN \\ Pennsylvania State University, USA \\ Cemal EKIN \\ Providence College, USA \\ Mehmet KUMBARACI \\ PISA Tekstil A.S. Turkey
}

\begin{abstract}
This paper explores the Turkish apparel industry and business strategies of firms by examining the core paradigms that have guided the industry over decades. It presents the current state of industry as manifest in the companies' core strategies within a strategic fit framework. It identifies the current problems faced by Turkish clothing manufacturers and marketers in this international industry. Then the paper offers some recommendations to foster the competitiveness of Turkish apparel firms. Finally, it draws conclusions by comparing the business behavior and strategies of Turkish firms by defining the structural and firm-specific factors.
\end{abstract}

This paper explores the business strategies of Turkish apparel firms by examining the core paradigms that have guided the industry over decades. It will present the current state of industry as manifest in the companies' core strategies, segmentation, product development and branding, and subcontracting within a strategic fit framework. The paper will address several critical questions: What are the major industry groups and who are the principal players in the industry? What are their core business strategies (i.e., low cost leadership or differentiation)? How successful are they in developing brands? How do they segment the market (e.g., based on demographics, income levels, etc.)? To what extent do Turkish apparel firms target foreign markets? What kind of strategic alliances do they form with foreign firms, if any?

The paper will consist of the following sections. The first part will present a strategic fit model to analyze the structure, behavior, and strategies of Turkish apparel firms. The second section will identify the current problems faced by such firms in this particular sector. The third section of the paper will offer some recommendations to foster the business performance of Turkish apparel firms. Finally, it will draw conclusions by comparing the business behavior and strate- gies of Turkish firms by defining structural and firmspecific factors.

\section{STRATEGIC FIT MODEL}

To analyze business strategies of firms, the concept of "strategic fit" has been used frequently in business literature. This concept is based on contingency theory, which is concerned with the "fit" between environmental conditions and the firm structure and strategy. Fit is often defined as alignment among the organizational components and/or its adaptation to its external environment (Ginsberg and Venkatraman, 1985; Grant 1998; Miles and Snow 1994; Venkatraman and Camillus, 1984; Venkatraman 1989). "One of the most widely shared and enduring assumptions in the strategy formulation literature is that the appropriateness of a firm's strategy can be defined in terms of its fit, match, or congruence with the environmental or organizational contingencies facing the firm" (Zajac et al., 2000: 429). Similarly, Bourgeois (1980) and Venkatraman and Prescott (1990) emphasize the importance of the firm and environment interfaces in strategy formulation. Strategic fit is a core concept in normative models of strategy formulation, and the pursuit of strategic fit has traditionally been viewed as having desirable performance implications (Ginsberg and Venkatraman, 1985; Miles and Snow, 1994; Zajac et al., 2000).

Likewise, Fuchs and his colleagues (2000) suggest the key dimensions of effective strategy development and implementation as orchestrating all the elements of strategy around a powerful core theme and alignment of coherent product-market focus supported by operating capabilities and resources. Moving from this strategic fit premise, we offer a model in which the strategies Turkish apparel firms and apparel market conditions can be examined. Using a variant of the "strategic fit model," this paper will study the salient characteristics and dynamics of apparel marketing in 
Turkey. This model will help in analyzing and developing business strategies and marketing approaches for the firms operating in Turkey. The model posits that a strategic fit must exist between company profiles (resources and capabilities) and external environments in order for firms to succeed in their businesses through designing and implementing suitable strategies. In other words, it assumes that the firms succeed to the extent that they find and capitalize on such a fit by establishing appropriate structures and business strategies.

Our strategic fit model consists of three main components as depicted in Figure 1. The first component, external environment, has a direct or indirect influence on the formulation and implementation of business and marketing strategies that the firms may follow. It encompasses such environmental influences as customer demands, strategic groups, market segments, key success factors, economic, technological, governmental, and social factors, and key trends and changes. The second component, company profiles, considers sizes, goals, resources, capabilities, and cost and organization structures of companies. Company profiles reflect the characteristics of major players and their core competencies. The third component, company strategies, refers to principal strategic emphasislow cost leadership, differentiation, focus, and alliance strategies-that Turkish apparel firms use in marketing their products both domestically and internationally.

\section{External Environment}

The business environment of the apparel industry and businesses consists of all the external influences that affect firms' strategies and performances (Grant, 1998; Miles and Snow 1994). Therefore, the model considers a vast number of environmental influences, which shape up the apparel industry and businesses. In addition, by focusing on the industry environment, we can identify the vital macro level influences for the firms. Traditionally, strategic fit model is used to analyze the alignment between a firm and its environment, but we apply the model for all the firms rather than a single firm. Because the main thrust of this study is to portray the competitive dynamics in the Turkish apparel industry rather than display the competitive advantage of a single firm.

\section{Market Conditions}

The global apparel market has been changing under the influence of many factors. Critical observations germane to this study are: "(a) Developed economies have been shifting textile and apparel production to developing economies; (b) four major production blocks seem to emerge as the main competitors for this shifting production capacity: China, India, Latin and South America, and Pan European and Mediterranean regions; (c) firms from these blocks will not only engage in outsourcing but will also market their own products; and (d) the utilization of artificial and synthetic materials will exceed natural ones." (Turkish Clothing Industry, 2003:4)

Turkey with a population of about of 66 million people constitutes a large domestic market for apparel products. Given its cotton growing capacity and textile manufacturing capabilities, the textile industry has been a leading sector in the country stimulating both

\section{Figure 1 Strategic Fit Model}

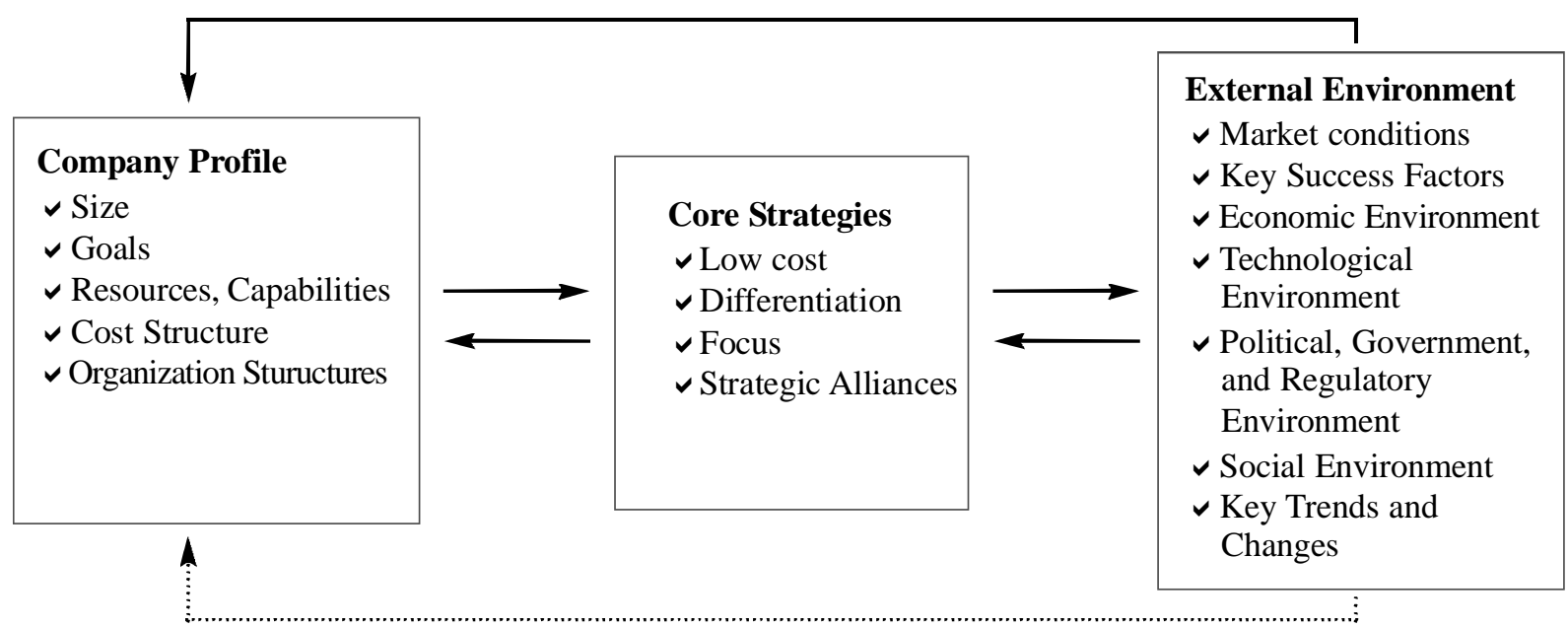

Primary strategic flows

Information, feedback 
industrialization and economic development. Additionally, Turkey's close economic relations with Europe have enhanced its apparel trade with major European countries including Germany, the Netherlands, and other EU countries. Moreover, the collapse of former Soviet Union and emergence of a number of Turkic republics have enticed the trade between Turkey and Russia and such Turkic republics as Azerbaijan and Kazakhstan.

Although textile manufacturing had thrived, the development of the domestic apparel market has become a vital sector since the 1970s due to increasing private sector investments in textile, fabric production, weaving, and dying. The government supported these investments by import substitution policies and tax incentives for investors and tax rebates for exports. In this period, the primary market for apparel industry remained in the domestic realm, and the migration to urban centers, as explained in a later section, supported the industry.

In the 1980's, market economy and export orientation accelerated, primarily in the form of subcontracting. The apparel industry emerged as a strong part of the economy and Turkish exporters entered the markets of Iraq, Libya, and the EU especially through Germany.

In the 1990's the focus has shifted more towards production and Turkey became the major supplier of apparel to the EU and grew to be the production and distribution center of large German, Dutch, and the U.S. firms. In 1996, Turkey signed a custom union agreement with the EU, which had implications in such areas as product quality, production productivity, environment, and firm social responsibilities. Subsequently, it became the second biggest supplier of apparel to the EU and the fifth biggest exporter in the world. Around this time, Turkish firms entered the U.S. markets as well. The apparel sector seems to have moved towards product development, original design, and brand development in 2000's. The future will likely bring national chains and increasing trade with the neighboring countries.

Porter's (1990) diamond model on competitive advantage of nations aptly explains the development of the Turkish apparel industry and the competitiveness of the Turkish firms. The application of Porter's diamond model to Turkish apparel industry reflects that all the components of the model were in place. For example, the following conditions were present: factor conditions (e.g., an integrated structure of cotton, textile, and garment production, availability of cheap labor), demand conditions (e.g., growing Turkish population's needs for apparels), relating and supporting industries (e.g. highly developed textile industry), and strategy, structure, and rivalry (e.g., augmenting competition) in the industry. All these industry conditions influenced firms' competitive advantage positively in domestic and international markets as the diamond model attests.

Future projections of the world apparel production indicate the product categories will develop as shown in Table 1, which suggests that the volume-based sales are at the low end of the product spectrum (first two rows in the Table1) and the value-based sales are at the higher end (the rows 3-5 in the Table 1). A review of

Table 1

Changes in Globally Traded Product Groups

\begin{tabular}{|c|c|c|c|}
\hline \multirow[b]{2}{*}{ PRODUCTS } & \multicolumn{2}{|c|}{$\begin{array}{l}\text { Share in Total } \\
\text { Production }(\%)\end{array}$} & \multirow[b]{2}{*}{ TRENDS } \\
\hline & QTY. & VALUE & \\
\hline $\begin{array}{l}\text { Cheap, simple, mass } \\
\text { production products }\end{array}$ & 65 & 45 & $\begin{array}{l}\text { Lower price, more competition, less value share, compet- } \\
\text { itiveness based on cost }\end{array}$ \\
\hline $\begin{array}{l}\text { Fashion oriented } \\
\text { middle class batch } \\
\text { production products }\end{array}$ & 20 & 20 & $\begin{array}{l}\text { Same/higher price, more competition, bigger share in quanti- } \\
\text { ty and value, competitiveness based on cost and added value }\end{array}$ \\
\hline Customized products & 3 & 7 & $\begin{array}{l}\text { Higher price, higher share in value, competitiveness } \\
\text { based on creativity and added value }\end{array}$ \\
\hline $\begin{array}{l}\text { Expensive, luxury, } \\
\text { fashion-brand } \\
\text { products }\end{array}$ & 2 & 8 & $\begin{array}{l}\text { Higher price, competitiveness based on added value, } \\
\text { fashion and exclusiveness }\end{array}$ \\
\hline $\begin{array}{l}\text { High value, interactive, } \\
\text { multi-function products }\end{array}$ & 10 & 20 & $\begin{array}{l}\text { Rapidly increasing price, price determined by technology } \\
\text { know-how in developed countries, higher share in quantity and } \\
\text { value, competitiveness based on technology and know-how. }\end{array}$ \\
\hline
\end{tabular}

Source: Turkish Clothing Industry: Horizon 2010, Turkish Clothing Manufacturers' Association, Istanbul 2003. p 8. 
Table 1 reveals that the low-end products will account for $85 \%$ of the volume and $65 \%$ of the value, while the value-added products constitute $15 \%$ of the volume and $35 \%$ of the value of the total production. China and Hong Kong dominate the low-end, high-volume, and low-cost market. Since the Turkish apparel firms are losing their competitive advantages in the low-end of the product spectrum because of the increasing Chinese competitive threat, entering high-value product markets, a segmented and targeted marketing strategy will become imperative for the Turkish firms. Although, their market shares would be smaller, but they would position themselves better from a competitive perspective. They can achieve such a competitive shift with adopting the advanced technology, knowhow, and intellectual property, which are instrumental for those companies with competencies commensurate with the implied sophistication.

\section{KEY SUCCESS FACTORS}

Generally devoid of strategic marketing, the implicit de facto strategy of the Turkish apparel manufacturers appears to be one of low cost in the middle and the low end of the market, and differentiation at the high end. Given that the high-end product manufacturers like Vakko and Beymen primarily cater to the domestic market and that the majority of the apparel exports are in the middle to low end of the market, the key success factor clearly becomes cost containment. The cost advantage, however transitory it may be, stems from the economic activities of a substantial unregistered cottage industry (Baser et al., 2003). This advantage can be easily replicated, and often be beaten in global markets. It will likely expire as Turkey's bid to become a member of the EU intensifies. Therefore, the "key success factors" that will be relevant in the future will replace the factors that may appear important now. The new key success factors will be different from the current ones and will require a different set of organizational and marketing capabilities.

China and Hong Kong dominate the global apparel market with $18.1 \%$ and $12.2 \%$ shares respectively. (Turkish Clothing Industry, 2003) This pair combines low cost and large production capacity to dominate the world markets. The primary industry segments they cater to are the lower to middle end of the product spectrum as shown in Table 1. With its economies of scale, cheap labor, and integrated cotton, textile, and garment industries, China will beat any other exporter on price. The World Bank estimates that China will control nearly half of the world's clothing exports by 2010, up from 20\% today after the Multifiber Arrangement, an international pact that uses import quotas to regulate $\$ 350$ billion world trade in gar- ments expired in 2004. Strategically, going into a head-on competition with China and Hong Kong will result in failure for Turkish manufacturers who lack the relative cost advantage compared with these two. The alternative strategic path lies in targeting the high value product-market segments. There, the key success factors are substantially different from what Turkish apparel industry currently has. Thus, the key success factors emerging to cater to the high-value markets will include the following characteristics: (1) Creativity and intellectual property, (2) fashion design, and (3) advanced technology and know-how. We can conclude that a significant gap between the current and future key success factors will emerge. Consequently, a shake out in the apparel industry will likely happen as companies fail to realize the importance of changing paradigms in textile and apparel manufacturing and marketing. At the core of business strategies lies the idea of understanding the needs of the customers and allocating resources to meet those needs. This simple but fundamental idea will become the driving force in this industry in the future resulting in major changes in the composition of the apparel industry in Turkey. The future success factors require capital-intensive investments in developing human and technology resources that will likely cause consolidations and strategic partnerships with both domestic and international firms.

\section{SOCIAL ENVIRONMENT}

In the last several decades, Turkish society has gone through major changes, the ones most relevant to this paper being the large-scale migration to urban and metropolitan areas, as well as the changing workforce in both numbers and the changing nature of their work. The migration to urban areas, the increasing pressure of time, necessity of proper urban attire, and the increasing emphasis on instant gratification made ready-to-wear apparel an attractive domestic market. In the early 70 's, the ready-to-wear products primarily catered to the two ends of the domestic market: the very high end, e.g. Vakko, catering to upper middle and upper class markets, and the low end, e.g. IGS, that catered primarily to lower-middle to lower class end of the spectrum, the newly arrived residents of urban centers. Many men and women in the large middle class of the time still favored the hand tailored garments, for quality and price reasons.

Because of advanced communication technologies, Turkish consumers have exposed to high standards of living and quality products and services and started demanding similar goods to the ones offered in Western economies. As Culpan (2002) asserted, this kind of instant exposure to better goods has stimulat- 
ed consumer demands that were either nonexistent before or impossible to meet.

During the 80 's, the quality of ready wear garments has improved in part due to the manufacturers' desire to enter the export markets. The export-oriented period of the 80's brought with it the need for standardization, quality control, and better synthetic materials. At the same time, the expansion in businesses and increasing awareness of the Western life styles influenced the preferences of the consumers. Combined, these factors gave a significant boost to the ready wear apparel industry, both in quality and quantity.

Culturally inclined to favor and imitate the West, and generally meticulous, the middle class work force began to support the domestic portion of the apparel industry. Whereas in the early 70's only a few households had a television set, the 80 's and the 90 's experienced a substantial penetration of televisions into households even in the remote parts of the country. Independent and private television broadcasting, and later cable television and satellite technologies opened a wide window to the world. A wide spread of television broadcasting in Turkey has increased the awareness of the Western life-style and the Western products and services (Leavitt 1983). Many products began to cross the national boundaries and Turkish consumers developed needs for similar products to the ones consumed in the Western markets. Many elements of Western culture have entered the mindset of Turkish consumers and apparel was no exception.

\section{Technological Environment}

Technology has become an inseparable part of most processes, including manufacturing and communications. Two facets of technology are relevant for the apparel manufacturing industry. First, the manufacturing process has become technology enhanced with new equipment and new materials; second, information technology (IT) has become a key element in the operations of most, if not all, organizations.

\section{Technology in Textile and Apparel manufacturing}

On the supply-side, the 1990's period witnessed increasing competition, shorter product life cycles, need for quick turnaround for products, manufacturing shifting away from developed nations, and proximity to markets becoming less relevant. These conditions have changed the consumer preferences and consequently, the channel operations. The following summarize the result of these changes.
"The ready wear knowledge is developing into a science; The ready wear production has become a major industry; The rate of change in textile technology is driving the changes in the ready wear industry; The "knowledge content" of traditional and high-tech products creates value; The ready wear design and production have become more integrated; Fashion and design are more a function of technology than human resources; The industry is moving toward flexible production at a faster rate; Synthetic fiber use will exceed natural fibers in textile production." (Turkish Clothing Industry, 2003:56).

The above trends demonstrate that production of textile and ready wear products will strongly rely on technology. The use of advanced technology will be the key for those Turkish manufacturers, which capitalize on low cost production to sustain their competitive advantages.

Information Technology in Business and Marketing Management

IT use in operations has become an integral part of business life. It has been facilitating corporate accounting, office productivity applications, and creativity and innovation. The advent of the Internet has changed the fundamental mode of communication between producers and consumers as well as among the members of the supply chain. IT has affected all facets of business life in recent years. Because of information efficiencies, the cost and time savings occur when IT allows employees to perform their current tasks a higher level, assume additional tasks, and expand their roles in the organization due to advances in the ability to gather data and analyze data (Dewett and Jones, 2001). In addition, IT helps the fast and effective dissemination of knowledge in the firm. Prahalad and Hamel (1990), for example, suggest that it is not the level of knowledge a firm possesses which lead to innovation and competitive advantage, but the velocity with which it is circulated in the firm.

One of the consequences of this changing technology is the use of extranets that connect a diverse set of suppliers to procurement systems of major buyers in the world. Consequently, just-in-time inventories and just-in-time production schedules start working to optimize the logistics cost while maintaining high levels of customer service. Such IT has reduced the inventory levels of customers practically to nothing, lowering inventory related costs substantially.

The textile and apparel industries in Turkey have not 
yet adopted information technology as a strategic tool at this level of sophistication. This can be attributed to the small to medium size of the firms in the sector, and a general lack of understanding and appreciation of strategic management and marketing. Confounding the issue is the inadequate state of the telecommunications infrastructure and its related costs. The telecommunications infrastructure in Turkey has not developed to accommodate rapid and sophisticated information exchanges while the cost of its use has remained high.

\section{Company Profiles}

Although textile manufacturing has been the foundation of the Turkish apparel industry, in recent years the value created by the apparel firms has exceeded the value created in the textile industry. A comparison of the characteristics of textile and apparel firms reflects the importance of apparel firms. Table 2 compares the two along important dimensions.

Table 2

Comparison of Characteristics of Turkish Textile and Apparel Firms

\begin{tabular}{|l|l|}
\hline TEXTIL FIRMS & APPAREL FIRMS \\
\hline Big Companies & $\begin{array}{l}\text { Small/Medium-sized } \\
\text { companies }\end{array}$ \\
\hline Capital intensive & Labor intensive \\
\hline About 2000 companies & About 35000 companies \\
\hline $\begin{array}{l}\text { Infrastructure and } \\
\text { Knowledge established }\end{array}$ & $\begin{array}{l}\text { Only few with such } \\
\text { establishments }\end{array}$ \\
\hline Big and rigid structures & $\begin{array}{l}\text { Flexible and responsive } \\
\text { structures }\end{array}$ \\
\hline 500,000 Employment & $\begin{array}{l}2.5 \text { million } \\
\text { Employmentmulti }\end{array}$ \\
\hline
\end{tabular}

Approximately 35,000 small- and medium-sized, "cottage industry" type firms operate in the apparel industry. Mostly entrepreneurs with practical experience in the textile and apparel businesses, but with little or no formal business education, own and operate these firms with their families. They primarily offer subcontracting services in sewing, pressing, packing, and embroiling. Generally, they do not have foreign connections nor do they participate in international fairs or exhibitions.

In general, the Turkish apparel industry consists of exporters and non-exporters. Exporters differ based on the market that they serve. The American-oriented companies typically work with fewer models, larger quantities, fewer accessories, and with low profit margin. The European-oriented ones, on the other hand, deal with many models, smaller quantities, many accessories, and relatively high profits margins. However, these high margins sometimes quickly erode to levels below the lower margins of the American-oriented exporters due to small lots and export rejects after the quality control.

In addition to the traditional European and American export markets, two uniquely interesting export markets emerged in Turkey. The first market is "Laleli," a location in Istanbul, where tourists from Russia, Romania, and Bulgaria purchase apparel goods, take them back to their home countries, and sell them at a profit. The locals called this "luggage trade" which amounted to about $\$ 3$ billion. Despite its considerable size, much of this trade went unrecorded and in recent years, it has slowed down considerably tough.

In domestic cloth retailing, there are primarily three types: department stores (e.g., Atalar, Vakko, Beymen, Network), chain stores (e.g. Damat, Mudo, Polo) and independent stores. It was predicted that the clothing sales for differentiated goods will continue to move to departments and chain store from independent stores (Turkish Clothing Industry, 2003). In addition, emerging hypermarkets like CarrefourSA (French-Turkish), Real (German), and Migros (Turkish) in big cities present another type of general store chain.

Another substantial yet unregistered market has developed in tourist towns and resorts along the seashores, where tourists buy export-surplus or major brand knock-off apparel goods at significant savings. These cash-based transactions leave no records or traces while the customers get a chance to purchase quality goods like jeans, pants, T-shirts, shorts, swimwear, and towels, and other textile products at significantly reduced prices.

Moreover, producer factory outlets have become popular markets in recent years. They have been appearing in and around cities, and along major highways to reach both domestic and foreign visitors. An increasing number of factory outlets like Levi's, and Lee Coopers have mushroomed along intercity highways.

\section{Business Strategies}

Based on the source of competitive advantage and market scope, Porter (1980) defines four generic business strategies as low cost leadership, differentiation, focused low cost, and focused differentiation. The firm competitive advantage originates from either low cost operations or perceived uniqueness created by the firm for its products or services. The other important dimension, market scope, refers to a firm's target mar- 
ket. Consequently, the market scope could be broad or narrow. Companies attempt to either reach a broad market pursuing mass marketing, or target a carefully selected part of it through segmentation and target marketing. Whether they pursue mass or target marketing, low cost leadership and differentiation remain as two fundamental strategies. For the sake of simplicity and practicality, in this paper we consider the three distinct variants of low cost leadership, differentiation, and focus strategies, but add strategic alliances to the set of core strategies.

Firms often develop strategic alliances with other firms in the value chain activities especially in production and distribution. Beamish and Killing (1997), Contractor and Lorange $(1988 ; 2002)$ and Culpan (1993) argue that building inter-firm partnerships is a viable strategic option for many firms today. With increasing globalization and technological advances, strategic alliances have augmented Porter's three core strategies. This works particularly well in developing economies where companies need capital, technology, and marketing resources and capabilities. Such firms often form joint ventures or other types of alliances (i.e., licensing, franchising, and subcontracting) by offering what they have, their production capacity or local market access, in exchange for what they need, capital, technology, or marketing capabilities. In the worldwide apparel industry, Western companies commonly use subcontractors in developing economies to reduce their production costs. Western firms may also form joint ventures with local firms in developing countries to exploit cost advantages in the value chain activities.

A close examination of the Turkish apparel industry shows that the industry is very much fragmented. Firms in this industry range from a few medium to large major players to many small ones. They all engage in manufacturing or marketing of apparels, some do both. They present the following characteristics.

\section{Low-Cost Operators}

This refers to a group of more than 30,000 companies consisting small-sized manufacturers. The core strategy of this group is low-cost strategy. Using legally shaky and strategically weak methods, most of the companies in this group operate in the "unregistered sector." The low-cost strategy is based on primarily hiding the company records so as not to comply with minimum wages, paying employee health insurance premiums, and income taxes. By doing so, they minimize the cost of operations and stay competitive, no matter how short lived the cost advantage may be.

Although these firms mostly manufacture major brand knock-offs Lacost, Polo, Boss, Levi's, and serve the low-end domestic market, they present a major dilemma for the industry. On the one hand, the industry frowns upon them since they obtain an unfair advantage in domestic competition with firms operating within legal boundaries. On the other hand, a number of large firms use them as subcontractors for their export businesses. They do this ostensibly to combat the increasing labor wages and high-energy costs that make their prices unattractive to American and European companies searching for subcontractors to fulfill their manufacturing needs. This symbiotic relationship is very myopic and it puts the large companies together with the small cottage industry firms as they both try to implement a low-cost strategy in a market where low-cost leadership has moved to countries like China and Hong Kong.

\section{Differentiation Seekers}

Another group of companies uses quality leadership and channel control as their core business strategy. It includes Vakko (exclusive department store,) Beymen (fancy department store,) Ramsey (brand name,) Ipekyol (specialized informal women dresses,) Damat (targets young men; has stores in Madrid, Spain and in the USA,) Cotton (targets young women,) UKI and Sarar (producer and chain stores of men clothing). Some of these companies, like Vakko and Beymen, focus on the high-end of the domestic apparel market. Others have retail operations, which are either vertically integrated, (e.g., manufacture their own brands,) or subcontract their merchandise production to other manufacturers.

A small number of others, like Mavi (also markets in the USA and Western Europe,) PROMAR (Quick Silver, has stores in Moscow and in some Gulf countries), Colin Jeans (well known in Russia,) Motor Jeans (dominant in Bulgaria,) have successfully built brands not only recognized in domestic markets but in foreign countries as well. The core marketing strategy among this group appears to be brand management and franchising their brand domestically and internationally.

\section{Focusers}

Only a limited number of companies follow focus strategy by making and marketing clothes for military, police, and firefighters. These firms find and preserve their niche markets by segmenting the market and specializing producing clothes appealing to specific groups.

\section{Alliance Builders}

Strategic alliances between Western and Turkish firms may take the form of joint ventures, licensing, franchis- 
Table 3

List of major licensing agreementsa

\begin{tabular}{|l|l|l|}
\hline WESTERN LICENSORS & LOCAL LICENSEE & SUBJECT / TYPE \\
\hline Australian Sportswear Co. & Quick Silver & Young and Sportswear \\
\hline Polo & Park Bravo & Variety of apparel \\
\hline Lee & Soktas/Soke & Jeans; production \&chain store \\
\hline Lee Cooper & Konitex & Jeans; production \& chain store \\
\hline Levi's & A variety firms & Franchising jean stores \\
\hline
\end{tabular}

ing, and subcontracting agreements. However, the most common form of partnerships with Western companies is subcontracting arrangements. A number of Western apparel firms have contracts with major Turkish apparel firms. Table 3 lists some examples of this type of alliances between Western and Turkish companies.

In general, Turkish apparel firms engage in production and distribution licensing agreements with wellknown Western companies, through which they pay certain royalties to Western licensors. However, the licensing deals, except for a couple of big ones, have been losing its popularity.

The above-mentioned changing external environment, increased demand for ready wear products from developed countries, and Turkey's rising position as one of the leading textile manufacturers in the world signaled the need for a different business paradigm. Examining business strategies of Turkish apparel firms in the context of Porter's (1980) generic business strategy classification indicates that the Turkish apparel manufacturers and marketers neither followed a conscious strategy nor did they notice the shifting paradigms. To those strategically astute, these conditions should have signaled the need for segmentation-based strategy with carefully selected targets and appropriate marketing mixes offered to each. However, due to the nature of the apparel industry, which consists of a few mediumto-large companies peppered with many small cottage industry members, the Turkish apparel industry seems to have either missed or ignored this signal. To this day, the core business philosophy has remained largely product and production oriented with some necessary moves towards market orientation. A large number of the firms in the apparel industry in Turkey still follow a diminishing advantage of low-cost strategy.

\section{CURRENT PROBLEMS}

Explanations given within the framework of strategic fit model above illustrate that Turkish apparel industry has gone through an evolution, but this evolution has not been complete yet. Most firms are still small-sized cottage businesses. The transition from entrepreneurial to professional management has not yet completed its cycle, and these companies remain mostly as family-owned enterprises instead of becoming public companies. The lack of institutional structure and professional management will emerge as a serious problem for most of these firms as the government under the domestic and EU pressures eventually takes steps to transform the cottage businesses into legal entities. As a result, they may lose their competitive advantages and consequently face lower demand for their products and subcontracting services.

Globally the production cost advantages have been shifting quickly. For example, China has been a major supplier for many apparel products. Accordingly, Western firms have found cheaper and attractive subcontractors in China, Hong Kong, Bangladesh, and India. Under the pressure of increased costs of production factors such as high capital, labor, energy, and health insurance costs, and taxes on the one hand, and cost containment pressures from the Western contractors on the other hand, Turkish ready-wear manufacturers have been squeezed enormously. In addition, international low cost manufacturing sites have become havens for Western companies. Such a demand shift would eventually put Turkish apparel firms in jeopardy. Before facing such catastrophic outcomes, those Turkish firms relying on shaky low cost advantages need to revitalize their strategies and structures.

Furthermore, once attractive foreign markets like Russia have developed their own apparel industries instead of heavily depending on imports from Turkey. Although some of the export transactions have been unrecorded (e.g., luggage trade to Russia), Turkish ready-wear exports to Russia generally have been decreasing. This means either Turkish apparel firms need to enter these foreign markets more systematically, or find alternative markets to make up for their losses.

The lack of economies of scale presents a major prob- 
lem for many apparel firms in Turkey by preventing them from exploiting size advantages. Because, with the economies of scale proportionate increases for inputs used in the production process results in more than proportionate increases in the total output (Grand 1988). In addition, economies of scale advantages go beyond production process to other value chain activities as well. However, the fragmented Turkish apparel industry structure presents an obstacle to benefiting from scale economies while many firms heavily engage in low cost strategies. This situation needs the collective attention of the industry members as well as that of the government.

As illustrated above, a great number of Turkish readyto-wear manufacturers and marketers rely heavily on low cost leadership strategies, while in both domestic and global demands for brand name products are expected to increase in the future. Hence, it is time for Turkish apparel firms to become responsive to such changes in the marketplace and to develop differentiation strategies for quality and reasonably priced products as consumers become more informed and acquainted with international standards and brands.

Moreover, the use of advanced production and process technologies by the Turkish apparel companies is not at the level of competing Western or the even some of emerging country firms. The majority of Turkish companies in the apparel industry have not adopted technologies as a strategic competitive tool. Turkish firms need to embrace "knowledge content," "integrated design and manufacturing," and "flexible production" concepts as mentioned earlier when the technological environment discussed above. In addition, they have to espouse process technologies such as just-in-time management, enterprise resource planning, supply-chain management, and customer relations management. Furthermore, the methods of "total quality management (TQM)" should become a managerial focus not only for the firms pursuing differentiation and focus strategies, but also for firms following low cost strategies.

In adopting modern production and process technologies, Turkish apparel firms cannot afford to wait for a slow progression but need to make a quantum leap in this process. Therefore, they urgently need to invest into the development of their resources and capabilities by acquiring superior technologies and providing training to their personnel to use them.

\section{SOME RECOMMENDATIONS}

After examining the market environment of the apparel industry and the Turkish apparel firms' strategies, we recommend the following changes for the apparel firms. First, the apparel industry desperately needs formalization and consolidation. Although this large number of firms operating in the loosely structured cottage industry may seem efficient and nimble, they will not be able to operate in this fashion for long. Their competitive advantage is temporary. When they transform into legal structures, they will quickly lose their competitive advantages. Therefore, we recommend that they should bring their operations within the legal boundaries to a competitive level by consolidations. Presently they compete unfairly with other medium- and large-sized legal establishments. Soon, the EU will require that the EU candidate Turkey bring these cottage businesses into a legal context. Our purpose here is not to define or recommend public policies, but to develop initiatives for apparel firms to consider. Therefore, we advise that these firms should legalize their status and consolidate to gain real cost advantages stemming from economies of scale, and should adopt technologies and methods to become efficient producers. They should also adopt suitable business strategies such as low-cost, differentiation, focus or strategic alliances. Some companies, for instance, may well survive without much difficulty by simply shifting from low-cost to differentiation strategy or combining both strategies.

Second, we recommend that those firms choosing a low-cost strategy move their production facilities to the Anatolian region where low cost labor and energy are available. This may be easier to implement if the Turkish government could offer tax or other incentives to facilitate this move. Those located in and around Istanbul and Marmara region should consider following differentiation strategies because of availability of expertise, capital, and international contacts.

Third, we suggest that Turkish apparel firms in following differentiation and focus strategies should seriously consider developing their own brands of products to remain competitive in domestic and foreign markets. We believe that the future phase of market evolution would require players offering brand names and effectively using differentiation and somewhat focus (niche) strategies.

The move to a more robust strategic marketing management should incorporate the following: 1) bring a new level of sophistication to marketing and production management, 2) help develop a critical mass of knowledge and capital, and 3) lead to a better understanding of the importance of using technology in the apparel industry.

The above factors will cause Turkish apparel manu- 
facturers to start developing competitive strengths in the new apparel industry shaped by developed countries and emerging countries like China and India. In this venture, the key strategic factors will include such qualities as new knowledge, advanced production and process technologies, and efficient channels and supply chains, facilitated by information technology.

Fourth, if the Turkish government lags in undertaking major economic policies to improve the economic and technological infrastructure in order to reduce the cost of essential inputs (e.g., high cost of capital, labor, and energy,) some Turkish apparel firms should consider moving their production facilities into nearby European countries like Romania and Bulgaria where these factors are less costly. In fact, as Culpan and Akcaoglu (2003) pointed out, some Turkish firms have already moved their manufacturing activities into Eastern Europe, Russia, and the Turkic republics in Asia.

Fifth, because of increasing popularity of the Internet, Turkish apparel marketers should consider adopting the Internet as a strategic tool. In developed economies, business-to-consumer and business-tobusiness e-commerce have created new opportunities for the firms. Although presently the use of the Internet is limited in Turkey, it is expanding rapidly and will be a virtual market place soon. Since an increasing number of firms and consumers have been utilizing the Internet, online business models should enter Turkish firms' strategic repertoire.

Finally, the apparel firms of various sizes should seek strategic alliances in one form or another (e.g., joint venture, licensing, subcontracting) with other domestic or foreign apparel firms. In outsourcing, joint information networks between outsourcing firms and subcontractors facilitating continuous and instant information flow have become vitally important. Some effective and efficient applications such as just-in-time management systems (JIT,) flexible manufacturing $(\mathrm{FM}$,$) and enterprise resource planning (ERP,) rela-$ tionship marketing, and customer relations management (CRM) can be adopted through partnerships between Western firms and local manufacturers and marketers.

As individual companies remain medium to small in size in comparison to their foreign counterparts, a capacity consolidation may yield the necessary economies of scale in operations. Separating production from trade and consolidating several manufacturing concerns under one trade company may yield desirable outcomes. This will result in large trade companies dealing with the foreign buyers where they will have the advantages of economies of scale.

\section{CONCLUSION}

Apparel firms continue to encounter an increasingly networked, globalize world facing fast-paced technological, environmental, demographic, and cultural changes. We have explored ways to be proactive in the midst of such powerful forces and rapid changes. A central premise of strategic movement is that firms need neither accept change uncritically nor resist it blindly, but rather may strive to develop proactively new strategies to cope with existing problems and exploit market opportunities. After examining the external environment, company profiles and business strategies, we have identified the current problems and suggested some solutions as to how Turkish apparel firms can shape their future rather than merely float in without a rudder. In other words, we have recommended ways in which they can stay truly competitive by building viable and creative strategies.

As Grant (1998:13) aptly pointed out "Lack of consistency between the strategy pursued by a firm and its external and internal environments is a source of failure." Our strategic fit model demonstrates that the market environment of Turkish ready-wear firms has been changing rapidly while the company sizes, goals, resources, capabilities, and structures have not kept up with such changes. In addition, companies have not redesigned their strategies to acquire the necessary economies of scale, resource, and capabilities to respond the market changes. As we suggested, there is a need for Turkish apparel manufacturers and marketers to adopt business strategies emphasizing differentiation and focus strategies, or strategic alliances after engaging in a series of mergers and acquisitions.

The strategic fit model offered in this paper can help managers to identify, classify, and understand principal forces that affect strategic decisions. The same framework can help in analyzing the market and company forces and related issues, and in finding solutions to emerging problems. This approach will be useful not only for Turkish companies, but also for companies in similar developing markets where market and company infrastructures have not sufficiently developed. Firms in developing economies need to learn a great deal from Western counterparts in the areas of the state-of-the art production and marketing techniques (e.g., flexible manufacturing, just-in-time management systems, total quality management, customer relations management). Strategic alliances in the form of licensing, franchising, joint ventures, and subcontracting will be instrumental in sharing resources and 
capabilities for competitive advantage of the partnering firms.

We have focused on business strategies of Turkish apparel firms without addressing public policy issues, which we admit, are extremely important for fostering the industry. However, they are beyond the scope this paper. It must be noted, however, that the Turkish government should adopt certain measures such as adjusting energy, capital, and labor costs to the world prices and provide tax, or other suitable incentives to stimulate the industry. Otherwise, Turkish apparel firms will loose their competitive base by continuing their production in the country or seek manufacturing opportunities in other countries, which would be devastating for the Turkish economy while Turkey is trying hard to attract foreign investments.

A limitation of the paper is that we were unable to find firm-level market and financial information since most of the Turkish apparel firms are family-owned private companies. The lack of information has prevented us from doing empirical analyses of firms' performances and business strategies. As consolidations and legalization of firms commence and the companies become more transparent, we suppose that future researchers will have a better chance to gather firmlevel data in conducting empirical studies.

Nevertheless, the present paper offers a systematic analysis of Turkish apparel firms within a strategic fit framework by defining external environment, company profiles, and business strategies. Additionally, it has identified the critical problems of the apparel firms and provided some recommendations for those problems. This paper has tied the concepts and applications in a systematic fashion that will be a great guide for researchers and managers to understand dynamics of and insights into the Turkish apparel firms and their strategies. Furthermore, it presents a prominent model to study apparel industry and firms in other developing countries or a comparison of the business strategies of companies from developed and developing countries.

\section{REFERENCES}

Baser, D.D., Farrel, D., and Meen, D.E. 2003. Turkey's quest for stable growth, The McKinsey Quarterly 2003 Special Edition: Global Directions.

Beamish, P.W. and Killing, P.J. (Eds). 1997. Cooperative strategies: North American perspectives. San Francisco: The New Lexington Press.

Bourgeois, L. J. 1980. Strategy and environment: A conceptual integration. Academy of Management Review, 5(1): 25-40.

Contractor, F. J. \& Lorange, P. (Eds.) 1988.

Cooperative strategies in international business. Lexington, MA: Lexington Books.

Contractor, F. J. \& Lorange, P. (Eds.) 2002. Cooperative strategies and alliances. Oxford: Elsevier Science Ltd.

Culpan, R. 2002. Global business alliances: Theory and practice. Westport, CT: Quorum Books.

Culpan, R.(Ed.) 1993. Multinational strategic alliances. New York: International Business Press.

Culpan, R. \& Akcaoglu, E. 2003. An Examination of Turkish Direct Investment in Central and Eastern Europe and the Commonwealth of Independent States, in S.T. Marinova and M.A. Marinova (eds.), Foreign Direct Investment in Central and Eastern Europe, London: Ashgate Publishing., pp. 181-199.

Dewett, T. and Jones, G.R. 2001. The role of information technology in the organization: Review, model, and assessment, Journal of Management, 27: 313-346.

Fuchs, H.P., Mifflin, K.E, Miller, D. and Whitney, J.O. 2000. Strategic integration: Competing in the age of capabilities, California Management Review, 42 (3): 118-148.

Grant, R.M. 1998. Contemporary strategy analysis. Third Edition. Malden MA:

Leavitt, T. 1983. The globalization of markets, Harvard Business Review, May-June, 92-102.

Miles, R.E. and Snow, C.C. 1994. Fit, Failure and the Hall of Fame. Macmillan, New York.

Porter, M.E. 1980. Competitive strategy. New York: 
Free Press.

Porter, M.E. 1990. The competitive advantage of nations. New York: Free Press.

Prahalad, C.K. and Hamel, G. 1990. The core competency of the corporation, Harvard Business Review, May-June, 43-59.

Turkish Clothing Industry: Horizon 2010. 2003. Turkish Clothing Manufacturers' Association. Istanbul, Turkey.

Venkatraman, N. 1989. The concept of fit in strategy research: Toward verbal and statistical correspondence, Academy of Management Review, 14: 423444.

Venkatraman, N. and Prescott, J.E. 1990.

Environment-strategy coalignment: An empirical test of its performance implications. Strategic Management Journal, 11(1): 1-23.

Venkatraman, N. and Camillus, J.C. 1984. Exploring the concept of fit in strategic management, Academy of Management Review, 9: 513-525.

Zajac, E., Kraatz, M.S., \& Bresser, R.K.F. 2000.

Modeling the dynamics of strategic fit: A normative approach to strategic change, Strategic Management Journal, 21 (4): 429- 